\title{
PERHITUNGAN PROFIT ASURANSI UNIT LINK DENGAN SURRENDER VALUE MENGGUNAKAN METODE PROFIT TESTING
}

\author{
Hanny Panjaitan. ${ }^{1}$, I Nyoman Widana ${ }^{2}$, Kartika Sari $^{3}$ \\ ${ }^{1}$ Program Studi Matematika, Fakultas MIPA - Universitas Udayana [Email: adrielhanny@ gmail.com] \\ ${ }^{2}$ Program Studi Matematika, Fakultas MIPA - Universitas Udayana [Email: nwidana@yahoo.com] \\ ${ }^{3}$ Program Studi Matematika, Fakultas MIPA - Universitas Udayana [Email: sari_kaartika@yahoo.co.id] \\ ${ }^{\S}$ Corresponding Author
}

\begin{abstract}
Life insurance with surrender value is a type of insurance that allows the insured to cancel the contract. Unit-link life insurance is a combination of life insurance and investment. Profit testing method is used to find out the potensial loss or gain of unit link life insurance product. The aim of this research was to determine the potential benefits or losses of unit-linked life insurance product using a deterministic model. Results of this research are the profit obtained by the insurance company for an insurance participant aged 35 years with a sum Rp.300.000.000,00 and Rp.8.000.000,00 in annual premiums are Rp. 5.767.716,00.
\end{abstract}

Keywords: Life Insurance, Profit Testing, Surrender Value.

\section{PENDAHULUAN}

Berdasarkan Undang-Undang Nomor 2 Tahun 1992, asuransi merupakan perjanjian antara dua pihak yaitu pihak tertanggung dan pihak penangung. Dalam hal ini pihak penanggung mengikatkan diri kepada tertanggung dan pihak penanggung menerima premi asuransi dari pihak tertanggung, yang kemudian memberikan penggantian kepada tertanggung.

Secara umum asuransi dibagi menjadi dua, yaitu asuransi jiwa dan asuransi non jiwa. Asuransi jiwa merupakan usaha kerjasama dari sejumlah orang yang sepakat memikul kesulitan keuangan bila terjadi musibah terhadap salah seorang anggotanya (Sembiring, 1986). Asuransi jiwa dibagi menjadi dua yaitu asuransi jiwa tradisional dan asuransi jiwa modern. Asuransi jiwa tradisional terdiri dari asuransi jiwa berjangka, asuransi jiwa seumur hidup dan asuransi jiwa dwiguna, sedangkan asuransi modern terdiri dari asuransi jiwa universal dan asuransi jiwa unit link (Dickson et al, 2009). Asuransi modern dianggap lebih menguntungkan dibandingkan asuransi tradisional sehingga masyarakat lebih banyak berinvestasi pada asuransi modern. Produk unit link merupakan produk yang paling banyak diminati oleh masyarakat Indonesia, karena asuransi unit link mengandung unsur investasi (Sartika dan Adinugraha, 2013).

Seseorang yang mengikuti asuransi, ada kemungkinan tidak akan meneruskan kontraknya karena berbagai alasan, antara lain karena merasa tidak lagi membutuhkannya, tidak lagi menguntungkan bila meneruskan mengikuti asuransi, dan tidak sanggup lagi meneruskan kontrak asuransi. Jika tertanggung berhenti dari asuransi, maka ada perusahaan asuransi yang akan mengeluarkan sejumlah uang sebagai akibat dari pemutusan perjanjian asuransi yang disebut surrender value (Sembiring, 1986).

Penelitian terkait surrender value pada kasus asuransi jiwa kontinu telah dilakukan oleh Fajriani dkk (2013) dan sebagai hasil diperoleh bahwa nilai surrender value untuk kasus asuransi jiwa seumur hidup dan asuransi jiwa berjangka pada awal tahun kontrak bernilai negatif, sedangkan nilai surrender value asuransi jiwa endowment lebih kecil dari premi. Hal ini disebabkan pada permulaan tahun, uang yang dibayarkan digunakan untuk kebutuhan administrasi perusahaan asuransi tersebut yaitu bunga, pengadaan polis, pemeriksaan kesehatan, biaya agen, dan lain-lain.

Salah satu cara menghitung aliran kas dari perusahaan asuransi pada tiap akhir periode 
(akhir tahun atau akhir bulan) dari satu kontrak polis asuransi unit link disebut profit testing. Profit testing dapat digunakan untuk menghitung keuntungan atau kerugian yang didapat perusahaan asuransi. Penelitian terkait profit testing telah dilakukan oleh Erik dan Millington (2004), yaitu dengan mengembangkan model profit testing menggunakan spreadsheets untuk kasus asuransi jiwa tunggal dipengaruhi oleh tingkat pengembalian, biaya administrasi dan pengaruh surrender value. Sebagai hasil diperoleh nilai tingkat kematian menggunakan spreadsheets lebih tinggi yang mengakibatkan nilai tunai manfaatnya menjadi rendah. Selanjutnya Mandal (2016) melakukan analisis aliran kas asuransi unit link dengan pendekatan stokastik dan deterministik. Sebagai hasil diperoleh pada tahun ke-0 manfaat asuransi bernilai negatif sedangkan pada tahun ke-1, ke2 , dan seterusnya manfaat asuransi bernilai positif.

Pada penelitian sebelumnya telah dibahas perhitungan premi dengan surrender value untuk asuransi jiwa seumur hidup, asuransi jiwa berjangka, asuransi jiwa endowment. Oleh karena itu penulis tertarik untuk melakukan perhitungan profit asuransi unit link dengan surrender value menggunakan metode profit testing.

Selanjutnya, dibahas konsep-konsep yang digunakan dalam perhitungan profit asuransi unit link dengan surrender value menggunakan metode profit testing.

Dalam bunga majemuk, didefinisikan nilai diskonto dengan simbol $v$ untuk mempermudah penulisan yaitu:

$$
v=\frac{1}{1+i}
$$

Selain bunga majemuk, hal yang perlu diperhatikan dalam perhitungan profit testing adalah Tabel mortalitas.

Misalkan $l_{x}$ menyatakan jumlah pemegang polis berusia $x$ tahun dan $p_{x}$ menyatakan peluang pemegang polis berusia $x$ tahun akan tetap hidup selama 1 tahun, maka:

$$
p_{x}=\frac{l_{x+1}}{l_{x}}
$$

Lebih lanjut lagi, misalkan $l_{x+t}$ menyatakan jumlah pemegang polis berusia $x$ tahun mencapai usia $x+t$ tahun dan peluang pemegang polis berusia $x$ tahun akan tetap hidup selama $t$ tahun dinotasikan dengan ${ }_{t} p_{x}$ dirumuskan sebagai :

$$
{ }_{t} p_{x}=\frac{l_{x+t}}{l_{x}}
$$

Oleh karna itu, peluang pemegang polis berusia $x$ tahun meninggal sebelum mencapai usia $x+1$ tahun yang dinotasikan dengan $q_{x}$ dirumuskan sebagai:

$$
q_{x}=\frac{l_{x}-l_{x+1}}{l_{x}}
$$

Demikian juga, peluang pemegang polis berusia $x$ tahun meninggal sebelum mencapai usia $x+t$ tahun yang dinotasikan dengan ${ }_{t} q_{x}$ dirumuskan sebagai:

$$
{ }_{t} q_{x}=1-{ }_{t} p_{x}
$$

Selain bunga majemuk dan Tabel mortalitas, hal lain yang harus diperhatikan dalam perhitungan profit testing adalah besar dana pemegang polis. Besar dana pemegang polis bergantung pada premi yang dibayarkan serta return atau hasil investasi dari perusahaan asuransi. Oleh karena manfaat yang diberikan tidak menentu, perusahaan asuransi perlu melakukan perhitungan dengan metode profit testing. Profit testing dilakukan dengan menghitung diagram aliran kas untuk setiap peserta asuransi, sehingga dapat diketahui keuntungan atau kerugian yang didapatkan oleh perusahaan asuransi untuk setiap peserta asuransi (Dickson et al, 2009). $A P_{t}$ dinotasikan dari premi yang dialokasikan untuk setiap peserta asuransi pada saat $t$ tahun yang didapatkan dari porsi investasi dikalikan premi asuransi dan $F_{t}$ dinotasikan dari dana pemegang polis untuk setiap peserta asuransi pada saat $t$ tahun yang dirumuskan sebagai:

$$
F_{t}=\left(F_{t-1}+A P_{t}\right)\left(1+i_{t}^{f}\right)-M C_{t}
$$

dengan $M C_{t}$ dinotasikan dari besar biaya manajemen untuk setiap peserta asuransi pada saat $t$ tahun yang dirumuskan sebagai:

$$
\begin{aligned}
M C_{t}= & \text { biaya tahunan }+ \\
& \left(A P_{t}+F_{t-1}\right)(1+4,5 \%) 2 \%
\end{aligned}
$$

Sedangkan keuntungan yang diperoleh perusahaan untuk setiap peserta asuransi pada saat $t$ tahun dirumuskan sebagai:

$$
P r_{t}=U A P_{t}-E_{t}+l_{t}+M C_{t}-E D B_{t}
$$

Dengan, $U A P_{t}$ menyatakan besar premi yang tidak dialokasikan untuk setiap peserta asuransi pada saat $t$ tahun yang dirumuskan sebagai:

$$
U A P_{t}=P_{t}-A P_{t}
$$

Suku bunga bebas resiko yang digunakan dalam penelitian ini $6.0 \%$ sehingga bunga yang diperoleh perusahaan untuk setiap peserta asuransi pada saat $t$ tahun yang dirumuskan:

$$
I_{t}=U A P_{t} \times 6.0 \%
$$

Manfaat kematian yang didapat perusahaan asuransi untuk setiap peserta asuransi pada saat $t$ tahun yang dirumuskan sebagai: 


$$
E D B_{t}= \begin{cases}q_{35+t-1} \times & \\ R p 300.000 .000,00 & \text { jika } F_{t}>0 \\ R p 0,00 & \text { jika } F_{t} \leq 0\end{cases}
$$

Dengan $\quad \operatorname{Pr}=\left(\operatorname{Pr}_{0}, \operatorname{Pr}_{1}, \operatorname{Pr}_{2}, \ldots, \operatorname{Pr}_{t}\right)^{T}$, disebut profit vector yang merupakan keuntungan yang diharapkan pada setiap periode untuk asuransi unit link $t$ tahun. Perkalian profit vector dengan peluang hidup seseorang merupakan keuntungan yang diharapkan pada akhir periode dari kontrak polis, yang dirumuskan dengan (Dickson et al, 2009):

$$
\begin{aligned}
\Pi_{t} & ={ }_{t-1} p_{x} P r_{t} \\
\operatorname{dan} \Pi_{0} & =P r_{0}
\end{aligned}
$$

Vector $\Pi$ disebut profit signature untuk kontrak asuransi unit link $t$ tahun, dengan

$$
\begin{aligned}
\Pi & =\left(\Pi_{0}, \Pi_{1}, \Pi_{2}, \ldots, \Pi_{t}\right) \\
& =\left(P r_{0}, P r_{1},{ }_{1} p_{x} \operatorname{Pr}_{2}, \ldots,{ }_{t-1} p_{x} P r_{t}\right)
\end{aligned}
$$

Misalkan $r$ merupakan tingkat diskonto risiko, maka nilai sekarang dari profit signature $(N P V)$, dinyatakan sebagai:

$$
N P V=\sum_{t=0}^{n} \Pi_{t} v_{r}^{t}
$$

Seseorang yang mengikuti asuransi, ada kemungkinan tidak akan meneruskan kontraknya karena berbagai alasan. Jika tertanggung berhenti dari asuransi, maka perusahaan asuransi akan mengeluarkan sejumlah uang sebagai akibat dari pemutusan perjanjian asuransi yang disebut surrender value (Sembiring,1986). Dengan $W_{t}$ dinotasikan dari surrender value asuransi jiwa dinotasikan sebagai:

$$
W_{t}=\left(1-\beta_{t}\right) \times A P_{t-1}-M C_{t}
$$

\section{METODE PENELITIAN}

\section{A. Jenis dan Sumber Data}

Penelitian ini mengunakan data sekunder, yaitu data dari Tabel Mortalitas Indonesia 2011. Dalam penelitian ini dilakukan simulasi perhitungan profit asuransi unit link dengan surrender value menggunakan metode profit testing untuk peserta asuransi dengan usia awal 35 tahun dan masa pertangungan asuransi 10 tahun dengan uang pertanggungan $\mathrm{Rp}$ 300.000.000,00.

\section{B. Teknik Analisis} adalah:
1. Menghitung nilai peluang waktu sisa hidup menggunakan tabel mortalitas untuk usia tertanggung 35 tahun.

2. Melakukan perhitungan profit Testing dengan surrender value untuk usia 35 tahun, dengan langkah-langkah:

a. Menentukan besar premi yang dialokasikan pada saat $\mathrm{t}\left(A P_{t}\right)$.

b. Menghitung besar bunga dari aset pemegang polis pada saat $\mathrm{t}\left(i_{t}^{f}\right)$.

c. Menentukan besar biaya menajemen pada saat $\mathrm{t}\left(M C_{t}\right)$.

d. Menghitung dana pemegang polis pada saat $\mathrm{t}\left(F_{t}\right)$.

e. Menghitung besar premi yang tidak dialokasikan pada saat $\mathrm{t}\left(U A P_{t}\right)$.

f. Menghitung besar biaya yang dikeluarkan perusahaan pada saat $\mathrm{t}\left(E_{t}\right)$.

g. Menghitung besar bunga yang dikeluarkan perusahaan asuransi pada saat $\mathrm{t}\left(I_{t}\right)$.

h. Menghitung manfaat kematian yang diharapkan pada saat $\mathrm{t}\left(E D B_{t}\right)$.

i. Menghitung manfaat surrender value $\left(W_{t}\right)$.

j. Menghitung total keuntungan yang diperoleh perusahaan pada saat $\mathrm{t}\left(P r_{t}\right)$.

k. Menghitung Profit Signature pada saat $\mathrm{t}$ $\left(\Pi_{t}\right)$.

1. Menghitung Net Present Value (NPV).

Pengolahan data pada penelitian ini menggunakan Software Microsoft Excell.

\section{HASIL DAN PEMBAHASAN}

Pada bab ini dibahas perhitungan profit pada perusahaan asuransi jiwa unit link dengan surrender value menggunakan metode profit testing. Studi kasus dalam penelitian ini akan membahas kontrak asuransi unit link pada perusahaan asuransi untuk usia tertanggung 35 tahun masa pertanggungan selama 10 tahun besar premi tahunan yang dibayarkan $R p 8.000 .000,00$. dan uang pertanggungan $R p 300.000 .000,00$. Sedangkan biaya asuransi bulanan dikenakan $R p 80.000,00$. pada penelitian ini akumulasi dari bunga yang diberikan oleh perusahaan diasumsikan bunga investasi 4,5\% dan bunga asuransi 6,0\%. Besar biaya administrasi setiap bulannya 
Rp18.000,00 dan biaya pengelolaan setiap tahunnya $2 \%$ yang dibayarkan selama berlakunya asuransi. Premi tahunan yang dibayarkan dibagi menjadi 2 yaitu Premi Berkala dan Premi Top Up, dengan pembagian Premi Berkala sebesar Rp5.000.000,00 dan Premi Top Up sebesar Rp3.000.000,00. Besar alokasi premi setiap tahunnya disajikan dalam Tabel 3.1.

Tabel 3.1 Persentase Investasi

\begin{tabular}{|c|c|c|}
\hline \multirow{2}{*}{} & \multicolumn{2}{|c|}{ Porsi Investasi } \\
\cline { 2 - 3 } & $\begin{array}{c}\text { Premi } \\
\text { Berkala }\end{array}$ & $\begin{array}{c}\text { Premi Top } \\
\text { Up }\end{array}$ \\
\hline Tahun ke-1 & $0 \%$ & $95 \%$ \\
\hline Tahun ke-2 & $40 \%$ & $95 \%$ \\
\hline Tahun ke-3 & $85 \%$ & $95 \%$ \\
\hline Tahun ke-4 & $85 \%$ & $95 \%$ \\
\hline Tahun ke-5 & $85 \%$ & $95 \%$ \\
\hline Tahun ke-6 dst & $100 \%$ & $95 \%$ \\
\hline
\end{tabular}

Pada Tabel 3.1, premi berkala belum membentuk investasi pada tahun pertama, sehingga pemotongan pada tahun pertama dilakukan pada tahun ketiga. Biaya akuisisi dari ilustrasi kontrak dibebankan pada premi berkala yang tidak diinvestasikan. Dalam penelitian ini diasumsikan tidak adanya penarikan investasi dan penambahan premi. Jika investasi yang terbentuk tidak cukup untuk membayar biaya administrasi dan biaya asuransi maka kontrak polis dianggap batal.

Selanjutnya, dalam Tabel mortalitas berjangka yang berisi $p_{x+k},{ }_{k} p_{x}$, dan $q_{x+k}$. Nilai $p_{x+k},{ }_{k} p_{x}$, dan $q_{x+k}$ untuk $k=1,2,3, \ldots 10$ dapat dilihat pada Tabel 3.2.

Tabel 3.2 Tabel Mortalitas Berjangka

\begin{tabular}{|l|l|l|l|}
\hline $\mathrm{k}$ & \multicolumn{1}{|c|}{$\boldsymbol{p}_{\boldsymbol{x}+\boldsymbol{k}}$} & \multicolumn{1}{|c|}{${ }_{\boldsymbol{k}} \boldsymbol{p}_{\boldsymbol{x}}$} & \multicolumn{1}{|c|}{$q_{\boldsymbol{x}+\boldsymbol{k}}$} \\
\hline 1 & 0.99909 & \multicolumn{1}{|c|}{1} & 0.00091 \\
\hline 2 & 0.99901 & 0.998101 & 0.00099 \\
\hline 3 & 0.99891 & 0.997013 & 0.00109 \\
\hline 4 & 0.9988 & 0.995817 & 0.0012 \\
\hline 5 & 0.99865 & 0.994472 & 0.00135 \\
\hline 6 & 0.99847 & 0.992951 & 0.00153 \\
\hline 7 & 0.99825 & 0.991213 & 0.00175 \\
\hline 8 & 0.99804 & 0.98927 & 0.00196 \\
\hline 9 & 0.99781 & 0.987104 & 0.00219 \\
\hline 10 & 0.99754 & 0.984675 & 0.00246 \\
\hline
\end{tabular}

Pada penelitian ini premi yang dibayarkan oleh tertanggung setiap tahunnya $R p$ 8.000.000,00 selama 10 tahun, yang terdiri dari premi asuransi sebesar $R p 5.000 .000,00$ dan premi investasi sebesar $R p 3.000 .000,00$. Besar persentasi dari premi yang dialokasikan menjadi dana pemegang polis dapat dilihat pada Tabel 3.3.

Tabel 3.3 Premi yang Dialokasikan

\begin{tabular}{|c|c|}
\hline $\mathrm{t}$ & $\mathrm{AP}_{\mathrm{t}}$ \\
\hline 1 & 2850000 \\
\hline 2 & 4850000 \\
\hline 3 & 7100000 \\
\hline 4 & 7100000 \\
\hline 5 & 7100000 \\
\hline 6 & 7850000 \\
\hline 7 & 7850000 \\
\hline 8 & 7850000 \\
\hline 9 & 7850000 \\
\hline 10 & 7850000 \\
\hline
\end{tabular}

Selanjutnya, besar bunga dihitung berdasarkan jumlah premi yang dialokasikan pada saat $t$ dan jumlah uang dari investasi yang digunakan adalah konstan $4,5 \%$,

$$
i_{t}^{f}=\left(A P_{t}+F_{t-1}\right) 4,5 \%
$$

Nilai $i_{t}^{f}$ untuk $t=1,2,3, \ldots 10$ dapat dilihat pada Tabel 3.4.

Tabel 3.4 Bunga Dana Pemegang Polis

\begin{tabular}{|c|c|}
\hline $\mathrm{t}$ & $i_{t}^{f}$ \\
\hline 1 & 128250 \\
\hline 2 & 352271.25 \\
\hline 3 & 687623.45 \\
\hline 4 & 1038066.51 \\
\hline 5 & 1404279.50 \\
\hline 6 & 1820722.08 \\
\hline 7 & 2255904.57 \\
\hline 8 & 27100670.28 \\
\hline 9 & 3185900.44 \\
\hline 10 & 3682515.96 \\
\hline
\end{tabular}

Lebih lanjut lagi, biaya manajemen dalam contoh kasus ini meliputi biaya asuransi, biaya pengelolaan, dan biaya administrasi. Biaya manajemen dievaluasi setiap tahunnya, biaya asuransi dan biaya administrasi terlebih dahulu dikonversikan menjadi biaya tahunan. Tingkat bunga perusahaan tahunan yang digunakan dalam penelitian ini $6,0 \%$, sehingga tingkat bunga bulanan yang digunakan, 


$$
\begin{array}{lll}
(1+x)^{12} & = & (1+0,06) \\
(1+x) & = & (1,06)^{\frac{1}{12}} \\
1+x \quad= & 1,004867 \\
x=0,004867 & \text { atau } 0,4867 \%
\end{array}
$$

Langkah berikutnya, pembayaran bulanan dikonversikan menjadi tahunan dengan faktor tingkat bunga bulanan 0,4867\% menjadi

$$
P_{12}=12,32649
$$

Artinya, pembayaran Rp1,00 setiap akhir bulan selama setahun, jika dibayarkan 1 kali dalam setahun (dibayarakan diakhir tahun) ekuivalen dengan Rp12,32649. Sebagai ilustrasi untuk usia tertanggung 35 tahun dengan biaya asuransi bulanan Rp80.000,00 dan biaya administrasi bulanan Rp18.000,00 ekuivalen dengan biaya tahunan senilai,

$$
\begin{gathered}
(R p 80.000+R p 18.000,00) 12,36289 \\
=R p 1.207 .996,00
\end{gathered}
$$

Besar biaya manajemen untuk setiap tahunnya dapat dihitung menggunakan persamaan (7). Sehimgga didapatkan nilai $M C_{t}$ untuk $t=1,2,3, \ldots, 10$ dapat dilihat dalam Tabel 3.5 .

Tabel 3.5 Biaya Manajemen

\begin{tabular}{|c|c|}
\hline$t$ & $M_{t}$ \\
\hline 1 & 1267561.099 \\
\hline 2 & 1371606.524 \\
\hline 3 & 2889345.219 \\
\hline 4 & 1519147.429 \\
\hline 5 & 1526471.689 \\
\hline 6 & 1549800.541 \\
\hline 7 & 1574179.191 \\
\hline 8 & 1583274.505 \\
\hline 9 & 1592779.108 \\
\hline 10 & 1602711.418 \\
\hline
\end{tabular}

Jika besar dana pemegang polis tidak mencukupi untuk membayar biaya admistrasi, biaya asuransi, dan biaya pengelolaan maka kontrak asuransi batal, sehingga besar dana pemegang polis berdasarkan persamaan (6) untuk usia tertanggung 35 tahun.

Dengan pemotongan biaya manajemen tahun ke-1 dilakukan pada tahun ke-3. Berikut dihitung dana pemegang polis untuk usia tertanggung 35 tahun. Nilai $F_{t}$ untuk $t=$ $1,2,3, \ldots, 10$ dapat dilihat dalam Tabel 3.6.
Tabel 3.6 Dana Pemegang Polis

\begin{tabular}{|c|c|}
\hline$t$ & $F_{t}$ \\
\hline 1 & 2978250 \\
\hline 2 & 6808915 \\
\hline 3 & 11707193 \\
\hline 4 & 18326112 \\
\hline 5 & 25303920 \\
\hline 6 & 33424841 \\
\hline 7 & 41956567 \\
\hline 8 & 50933963 \\
\hline 9 & 60377084 \\
\hline 10 & 70306888 \\
\hline
\end{tabular}

Premi yang tidak dialokasikan dapat dihitung menggunakan persamaan (9). Sehingga didapatkan nilai $U A P_{t}$ untuk $t=1,2,3, \ldots, 10$ dapat dilihat dalam Tabel 3.7

Tabel 3.7 Premi yang Tidak Dialokasikan

\begin{tabular}{|c|c|}
\hline $\mathrm{T}$ & $\mathrm{UAP}_{\mathrm{t}}$ \\
\hline 1 & 5150000 \\
\hline 2 & 3150000 \\
\hline 3 & 900000 \\
\hline 4 & 900000 \\
\hline 5 & 900000 \\
\hline 6 & 150000 \\
\hline 7 & 150000 \\
\hline 8 & 150000 \\
\hline 9 & 150000 \\
\hline 10 & 150000 \\
\hline
\end{tabular}

Biaya yang dikeluarkan dalam ilustrasi polis Perusahaan asuransi merupakan besar premi berkala yang tidak dialokasikan untuk investasi, dari Tabel 3.1 nilai $E_{t}$ untuk $t=1,2,3, \ldots, 10$ dapat dilihat dalam Tabel 3.8.

Tabel 3.8 Biaya Perusahaan

\begin{tabular}{|c|c|}
\hline $\mathrm{t}$ & $\mathrm{E}_{\mathrm{t}}$ \\
\hline 0 & 5000000 \\
\hline 1 & 0 \\
\hline 2 & 3000000 \\
\hline 3 & 750000 \\
\hline 4 & 750000 \\
\hline 5 & 750000 \\
\hline 6 & 0 \\
\hline 7 & 0 \\
\hline 8 & 0 \\
\hline 9 & 0 \\
\hline 10 & 0 \\
\hline
\end{tabular}

Suku bunga bebas risiko yang digunakan dalam penelitian ini $6.0 \%$, sehingga bunga yang diperoleh perusahaan untuk usia 35 tahun dapat dihitung menggunakan persamaan (10) yaitu : 


$$
I_{t}=U A P_{t} \times 6.0 \%
$$

Nilai $I_{t}$ untuk $t=1,2,3, \ldots, 10$ dapat dilihat dalam Tabel 3.9.

Tabel 3.9. Besar Bunga Perusahaan

\begin{tabular}{|c|c|}
\hline $\mathrm{t}$ & $\mathrm{I}_{\mathrm{t}}$ \\
\hline 1 & 309000 \\
\hline 2 & 189000 \\
\hline 3 & 54000 \\
\hline 4 & 54000 \\
\hline 5 & 54000 \\
\hline 6 & 9000 \\
\hline 7 & 9000 \\
\hline 8 & 9000 \\
\hline 9 & 9000 \\
\hline 10 & 9000 \\
\hline
\end{tabular}

Manfaat kematian yang ditanggung oleh perusahaan ketika tertanggung mengalami kematian berbeda-beda bergantung pada usia tertanggung. Dalam polis Perusahaan asuransi untuk usia tertanggung 35 tahun dengan uang pertanggungan Rp300.000.000,00. Manfaat kematian yang di dapat perusahaan dapat dihitung menggunakan persamaan (11). Sehingga didapatkan nilai $E D B_{t}$ untuk $t=$ $1,2,3, \ldots, 10$ dapat dilihat dalam Tabel 3.10.

Tabel 3.10. Manfaat Kematian

\begin{tabular}{|c|c|}
\hline$t$ & $\mathrm{EDB}_{\mathrm{t}}$ \\
\hline 1 & 273000 \\
\hline 2 & 297000 \\
\hline 3 & 327000 \\
\hline 4 & 360000 \\
\hline 5 & 405000 \\
\hline 6 & 459000 \\
\hline 7 & 525000 \\
\hline 8 & 588000 \\
\hline 9 & 657000 \\
\hline 10 & 738000 \\
\hline
\end{tabular}

Manfaat surrender value adalah manfaat yang dapat diklaim jika tertanggung memutuskan untuk membatalkan kontrak asuransi sebelum masa kontrak berakhir, dengan $\beta_{t}=70 \%$. Nilai $\mathrm{W}_{\mathrm{t}}=0$ pada 3 tahun pertama, menurut Dhaene et al (2017), hal itu disebabkan biaya tersebut akan digunakan untuk menutupi kerugian administrasi dan komisi yang besarnya dipengaruhi oleh nilai premi , dapat dihitung menggunakan persamaan (14). Sehingga didapatkan nilai $W_{t}$ untuk $t=1,2,3, \ldots, 10$ yang dapat dilihat dalam Tabel 3.11.
Tabel 3.11 Manfaat Surrender Value

\begin{tabular}{|c|c|}
\hline $\mathrm{T}$ & $\mathrm{W}_{\mathrm{t}}$ \\
\hline 1 & 0 \\
\hline 2 & 0 \\
\hline 3 & 0 \\
\hline 4 & 610853 \\
\hline 5 & 603529 \\
\hline 6 & 805200 \\
\hline 7 & 780821 \\
\hline 8 & 771726 \\
\hline 9 & 762221 \\
\hline 10 & 752289 \\
\hline
\end{tabular}

Sebagai ilustrasi, berikut dihitung profit vector untuk usia tertanggung 35 tahun menggunakan persamaan (8). Sehimgga didapatkan nilai $P r_{t}$ untuk $t=1,2,3, \ldots, 10$ dapat dilihat dalam tabel 3.12.

Tabel 3.12. Keuntungan Perusahaan

\begin{tabular}{|c|c|}
\hline $\mathrm{T}$ & $\mathrm{Pr}_{\mathrm{t}}$ \\
\hline 1 & 5186000 \\
\hline 2 & 1413606 \\
\hline 3 & 2766345 \\
\hline 4 & 752294.9 \\
\hline 5 & 721943.4 \\
\hline 6 & 444601.1 \\
\hline 7 & 427358.4 \\
\hline 8 & 382549 \\
\hline 9 & 332558.2 \\
\hline 10 & 271422.8 \\
\hline
\end{tabular}

Profit Signature merupakan keuntungan yang diperoleh perusahaan di akhir periode atau tahun dari 1 orang yang mengikuti kontrak, sehingga untuk usia 35 tahun dapat dihitung menggunakan persamaan (12). Sehimgga didapatkan nilai $\Pi_{t}$ untuk $t=1,2,3, \ldots, 10$ dapat dilhat dalam Tabel 3.13.

Tabel 3.13 Profit Signature

\begin{tabular}{|c|c|}
\hline $\mathrm{t}$ & $\Pi_{t}$ \\
\hline 1 & 5186000 \\
\hline 2 & 1410922 \\
\hline 3 & 1410922 \\
\hline 4 & 749147.7 \\
\hline 5 & 717952.6 \\
\hline 6 & 441446.9 \\
\hline 7 & 423603.2 \\
\hline 8 & 378444.3 \\
\hline 9 & 328269.5 \\
\hline 10 & 267263.4 \\
\hline
\end{tabular}

Keuntungan total yang diperoleh perusahaan dari satu kontrak polis asuransi dapat dihitung menggunakan persamaan (13) yaitu : 
$N P V=\sum_{t=0}^{n} \Pi_{t} v_{r}^{t}$

dengan nilai $v_{r}=\frac{1}{(1+6.0 \%)}=0.943396$.

Net Present Value dari profit signature untuk ilustrasi polis untuk usia tertanggung 35 tahun dengan masa pertanggungan 10 tahun adalah Rp.5.767.761,00. Nilai tersebut merupakan keuntungan yang diperoleh perusahaan untuk satu kontrak polis asuransi.

\section{SIMPULAN DAN SARAN}

Berdasarkan uraian pada hasil dan pembahasan, berikut diberikan kesimpulan dan saran sehubungan dengan penelitian.

\section{A. Simpulan}

Berdasarkan pemaparan pada bagian pembahasan, dapat disimpulkan bahwa profit yang diperoleh perusahaan untuk seorang peserta asuransi berusia 35 tahun dengan uang pertangungan $R p 300.000 .000,00$ dan premi $R p$ 8.000.000,00 adalah $R p$ 5.767.716,00.

\section{B. Saran}

Berdasarkan perhitungan yang telah dilakukan, penulis tidak melibatkan perhitungan cadangan dalam melakukan perhitungan profit testing. Disarankan untuk penelitian selanjutnya dalam melakukan pehitungan profit testing melibatkan perhitungan cadangan selain itu dapat manggunakan perhitungan tingkat bunga lainnya.

\section{DAFTAR PUSTAKA}

Dhaene, J., Godecharle, E., Antonio, K., Denuit, M., \& Hanbali, H., 2017. Lifelong Health Insurance Covers With Surrender Values: Updating Mechanisms In The Presence of Medical Inflation. ASTIN Bulletin: The Journal of The IAA. Vol.47 (3), pp. 803-836.

Dickson, D. C. M., Hardy, M.R. \& Waters, H.R., 2009. Actuarial Mathematics for Life Contingent Risk. New York: Cambridge University Press.

Ekawati, D., 2015. Penentuan Premi Tahunan Polis Partisipasi Asuransi Jiwa Endowment dengan Opsi Surrender. Thesis. Universitas Gadjah Mada.

Erik, dan Peter Millington. 2004. Profit Test Modeling in Life Assurance Using Spreadsheet part two.
Fajriani, N.A., Djuwandi \& Wilandari, Y., 2013. Perbandingan Nilai Tebus dan Cadangan Premi Pada Asuransi Jiwa Kontinu. Thesis. Universitas Diponegoro.

Futami, T., 1993. Matematika Asuransi Jiwa Bagian I. Tokyo: Oriental Life Insurance Cultural Development Center.

Mandal, Satrajit. 2016. Unit Linked Insurance Plans and Their Application in India. Thesis. Tartu University.

Undang-Undang No. 2 Tahun1992 tentang Usaha Perasuransian. Jakarta: Sekretarian Negara.

Sartika, M., \& Adinugraha, H. H. 2013. Konsep dan Implementasi Pengelolaan Dana Premi Unit Link Syari'ah. Jurnal Asuransi dan Manajemen Resiko, Vol.1, No.2. pp. 22-38.

Sembiring, R.1986. Buku Materi Pokok Asuransi I Modul 1-5. Jakarta: Karunika. 